\title{
Cold Climate HVAC 2018
}

The 9th International Cold Climate Conference Sustainable new and renovated buildings in cold climates Kiruna - Sweden 12-15, March 2018 



\section{Welcome to Kiruna and the Cold Climate HVAC 2018 conference!}

\author{
Dennis Johansson \\ Conference Chair \\ Lund University \\ Building Services
}

\author{
Åsa Wahlström \\ Senior Advisor \\ Lund University \\ Building Services
}

asa.wahlstrom@hvac.Ith.se

dennis.johansson@hvac.Ith.se hans.bagge@byggtek.Ith.se 


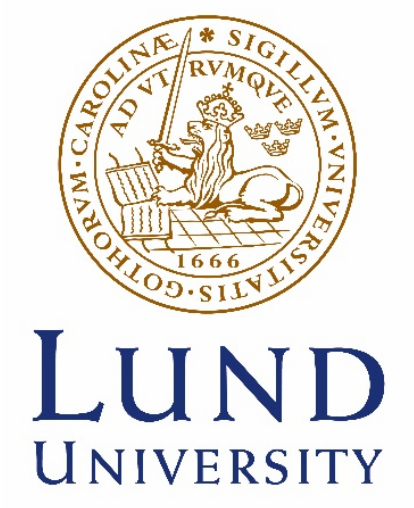

\section{Scantac}

Supporting organizations

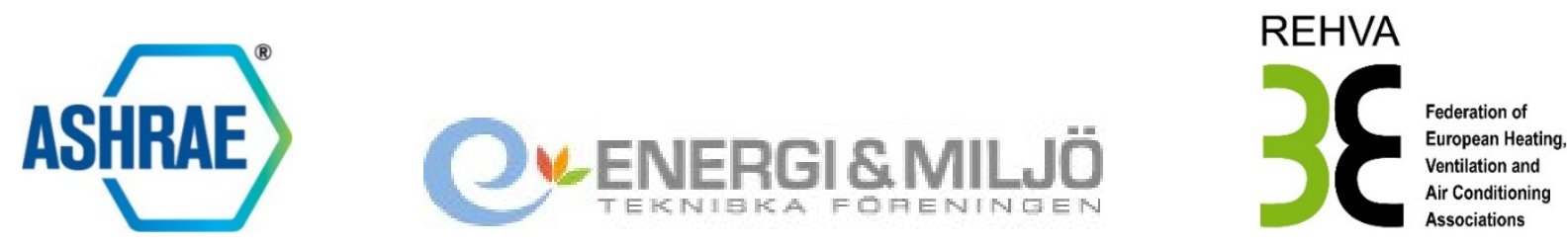


Gold partners

\section{CEMERTR}

iEIDELBERGCEMENTGroup

\section{aLKAB}

\section{클ABB}

Silver partners

咅amfil

CLEAN AIR SOLUTIONS

OcQ

Rent utan vatten och kemikalier

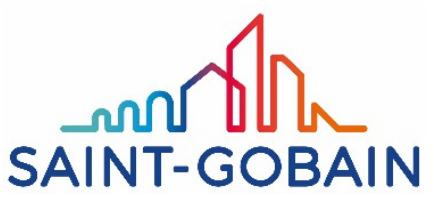

FläktGroup

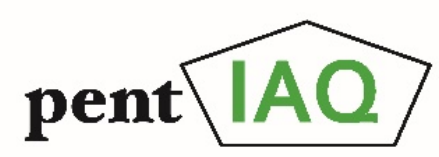

Analysis of indoor climate and energy

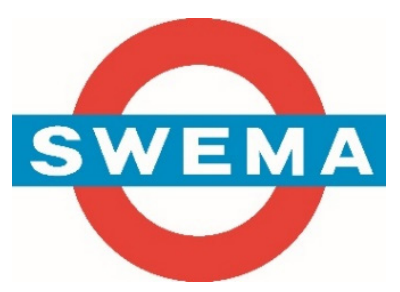




\section{Schedule}

\begin{tabular}{|c|c|c|c|c|c|}
\hline Monday & & Tuesday & Wednesday & Thursday & Friday \\
\hline \begin{tabular}{|l|}
$12: 00-16: 00$ \\
Pre conference tour
\end{tabular} & $8: 00-9: 30$ & \multirow[t]{4}{*}{$\begin{array}{l}\text { Bussride to mine } \\
\text { Keynote speakers } \\
\text { Guided tour }\end{array}$} & Keynote speaker & Fieldtrip & \multirow{6}{*}{$\begin{array}{l}\text { 9:00 - 13:30 } \\
\text { Post conference } \\
\text { Outdoor activities } \\
\text { Lunch }\end{array}$} \\
\hline $15: 00-16: 30$ & $9: 30-10: 00$ & & Coffe, exhibition & Coffe, exhibition & \\
\hline Meet and greet & $10: 00-12: 00$ & & Paper sessions & Paper sessions & \\
\hline \multirow[t]{2}{*}{$\begin{array}{l}17: 00-17: 15 \\
\text { Opening }\end{array}$} & & & & & \\
\hline & $12: 00-13: 00$ & Lunch, exhibition & Lunch, exhibition & Lunch, exhibition & \\
\hline \multirow{2}{*}{$\begin{array}{l}\text { 17:15 - 19:00 } \\
\text { Keynote speakers }\end{array}$} & & & & & \\
\hline & 13:00 - 14:30 & Paper sessions & Paper sessions & Paper sessions & \multirow{4}{*}{$\begin{array}{l}\text { 14:00 - 23:00 } \\
\text { Post conference tour } \\
\text { Abisko } \\
\text { Guided Tour } \\
\text { Aurora Hunting }\end{array}$} \\
\hline \multirow[t]{3}{*}{ Welcome reception } & $14: 30-15: 00$ & Coffe, exhibition & Coffe, exhibition & Coffe, exhibition & \\
\hline & $15: 00-17: 00$ & Paper sessions & \begin{tabular}{|l|} 
Fieldtrip \\
Icehotel
\end{tabular} & Keynote speaker & \\
\hline & & $\begin{array}{l}\text { Scientific } \\
\text { committe dinner }\end{array}$ & Conference dinner & & \\
\hline
\end{tabular}




\section{Monday}

12:00 - 16:30 Pre conference tour to Esrange space center (Separate registration required)

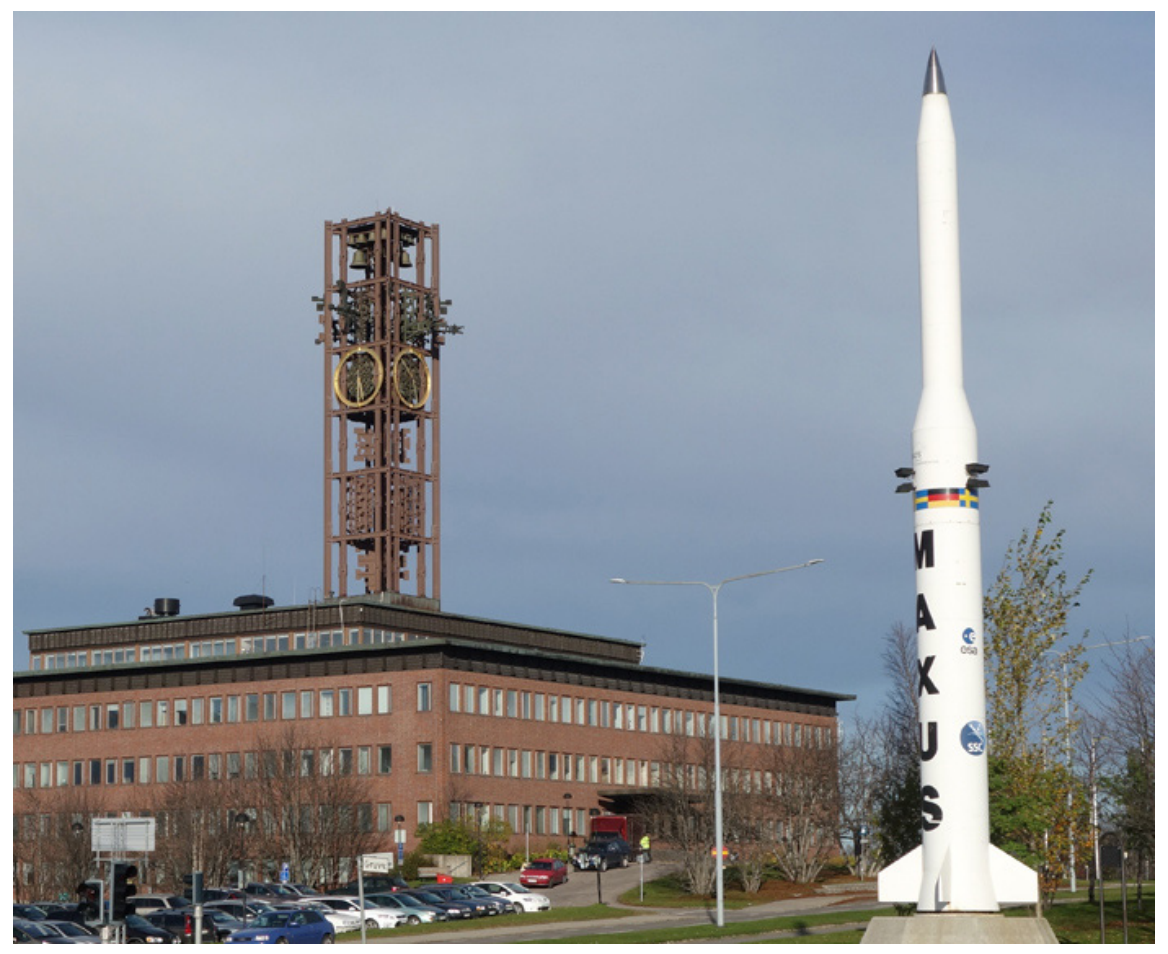

15:00 - 17:00 Meet \& Greet at Scandic Ferrum

17:00 Opening, Nåjdens sal, Kirunas Folkets Hus

17:15 Keynote speaker: Lars Bäckström - Head of Urban Development, Kiruna Municipality

Lars will be presenting some general information about Kiruna and the business life in Kiruna and the ongoing city transformation due to the expanding iron ore mine.

18:00 Keynote speaker: Kristina Mjörnell - Business and innovation area manager for Sustainable Cities and Communities, RISE Research Institutes of Sweden, Adjunct Professor in Building Physics, Lund University.

Kristina will be presenting transdisciplinary aspects on renovation in cold climates.

19:00 - 21:00 Welcome reception at Kiruna City Hall, Busses leave from Scandic Ferrum

ํำ 



\section{Tuesday}

\section{Group 1}

8:00 Bus leaves from Scandic Ferrum to the Iron ore mine.

\section{8:30 Guided tour}

9:30 Keynote speaker: Ulf Svennemyr and Håkan Ylvin - Project managers, Sweco UIf and Håkan will be presenting experiences from relocation of heritage buildings due to the expanding iron ore mine in Kiruna.

10:30 Bus leaves to Scandic Ferrum

\section{Group 2}

9:00 Bus leaves from Scandic Ferrum to the iron ore mine

9:30 Keynote speaker: Ulf Svennemyr and Håkan Ylvin - Project managers, Sweco Ulf and Håkan will be presenting experiences from relocation of heritage buildings due to the expanding iron ore mine in Kiruna.

10:30 Guided tour

\section{1:30 Bus leaves to Scandic Ferrum}

11:30 Lunch at Scandic Ferrum

13:00 - 14:30 Parallel paper sessions, detailed program on next page

Renovation of buildings

Building simulation

Indoor environment and health

14:30 - 15:00 Afternoon coffee, exhibition

15:00 - 17:00 Parallel paper sessions, detailed program on next page

Efficient HVAC components, Energy and power efficiency and low energy buildings Buildings in operation

Moisture safety and water damage, Trans disciplinary connections and social aspects

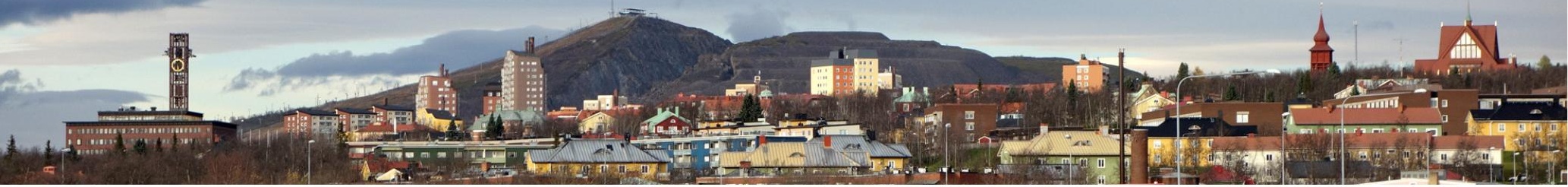




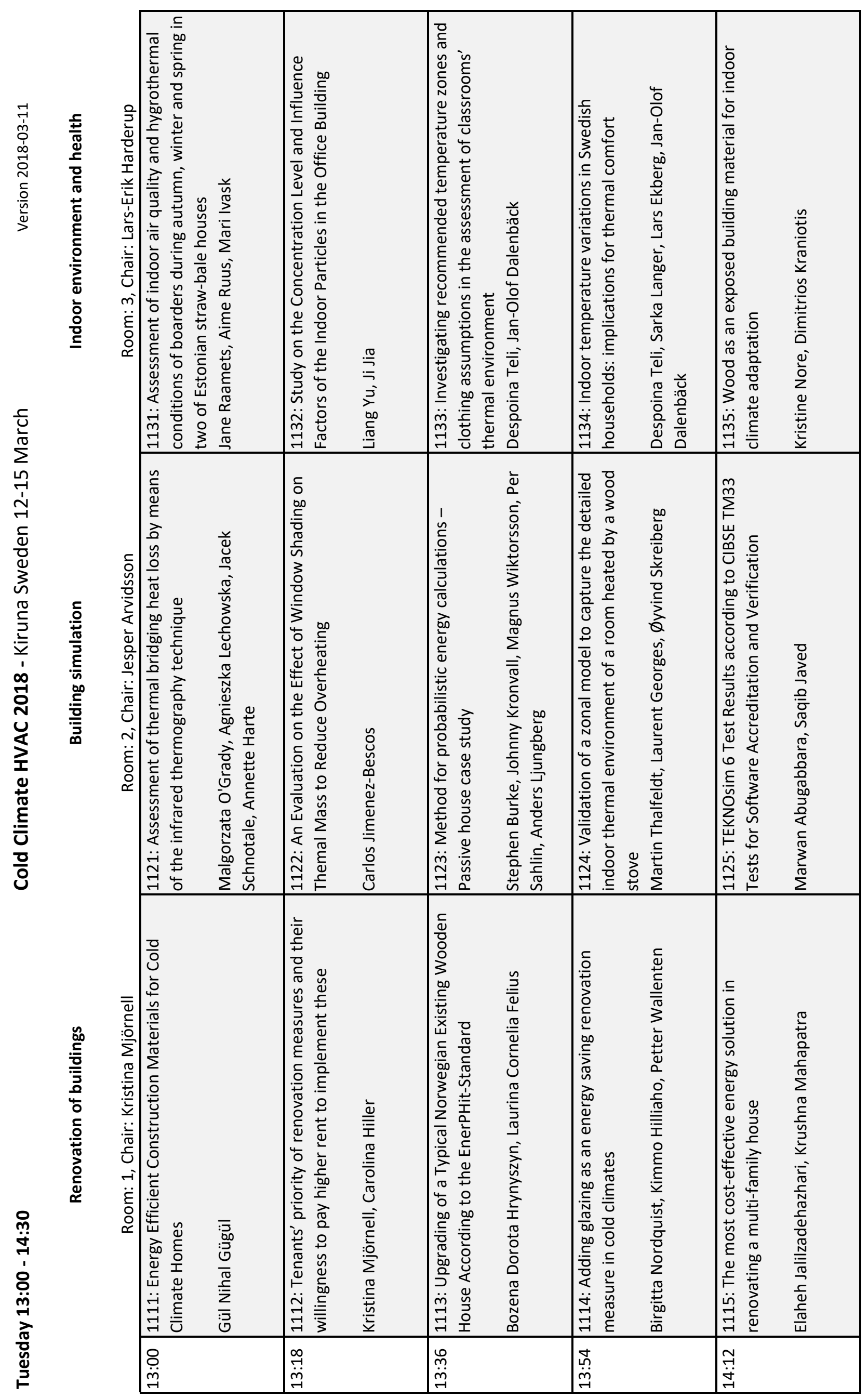




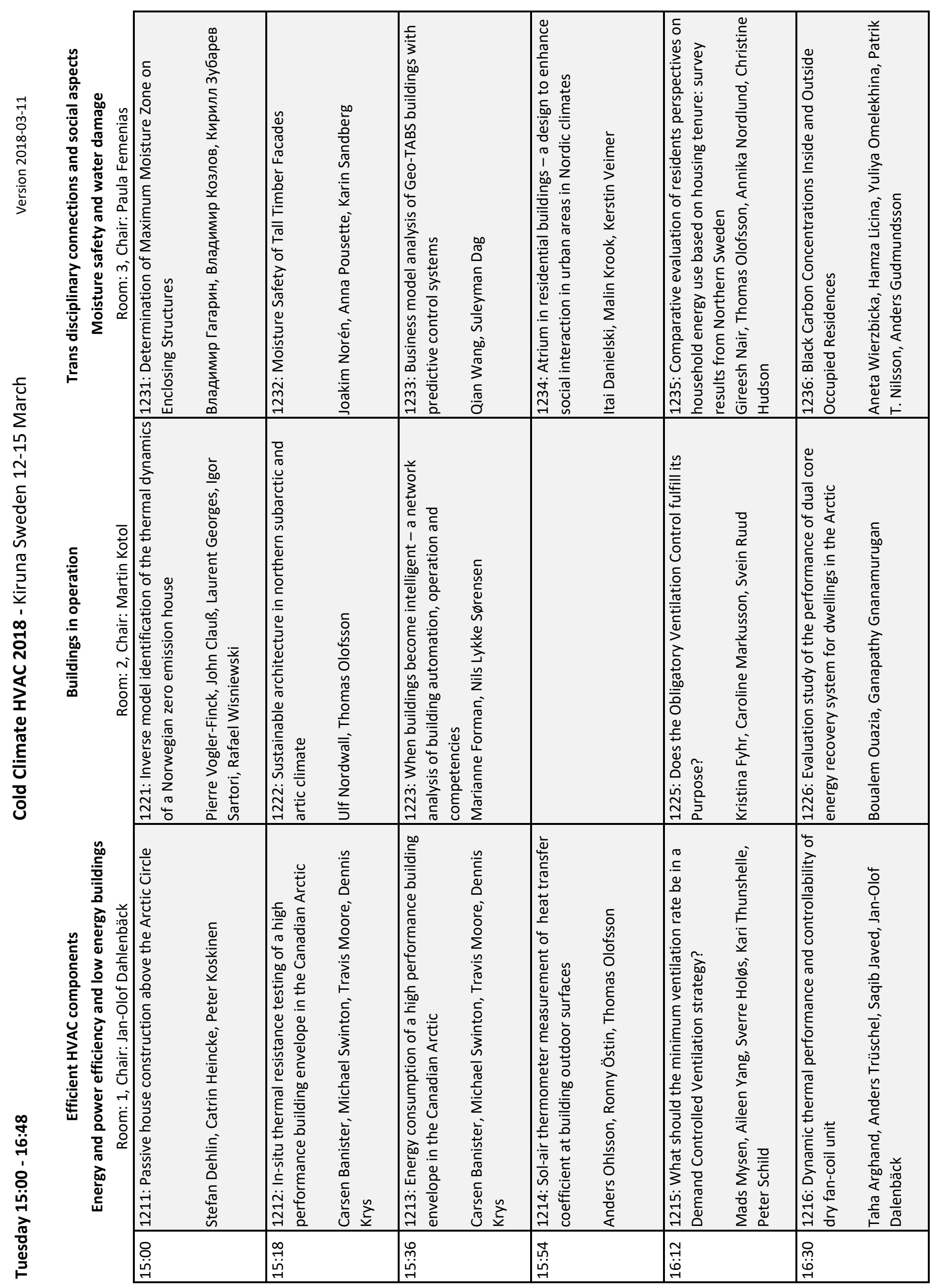





\section{Wednesday}

8:00 Keynote speaker: Arne Bergh - Creative Director, ICEHOTEL, Jukkasjärvi

Arne will talk about the icehotel and the new design and construction of ICEHOTEL 365, a new year round icehotel.

9:30 - 10:00 Morning coffee, exhibition

10:00 - 11:30 Parallel paper sessions

Energy and power efficiency and low energy buildings

Heat pump and geothermal systems

Buildings in operation, Building simulation

11:30 Lunch at Scandic Ferrum

13:00 - 14:30 Parallel paper sessions

Renovation of buildings

District and city energy systems

Building simulation

14:30 - 15:00 Afternoon coffee, exhibition

Fieldtrip to Icehotel Jukkasjärvi, guided tour.

Group A: Bus leaves Scandic Ferrum 15:00, bus leaves Icehotel 17:00

Group B: Bus leaves Scandic Ferrum 15:30, bus leaves Icehotel 17:30

Group C: Bus leaves Scandic Ferrum 16:00, bus leaves Icehotel 18:00

Conference dinner at Camp Ripan (separate registration required) busses leave Scandic Ferrum 18:30
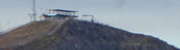


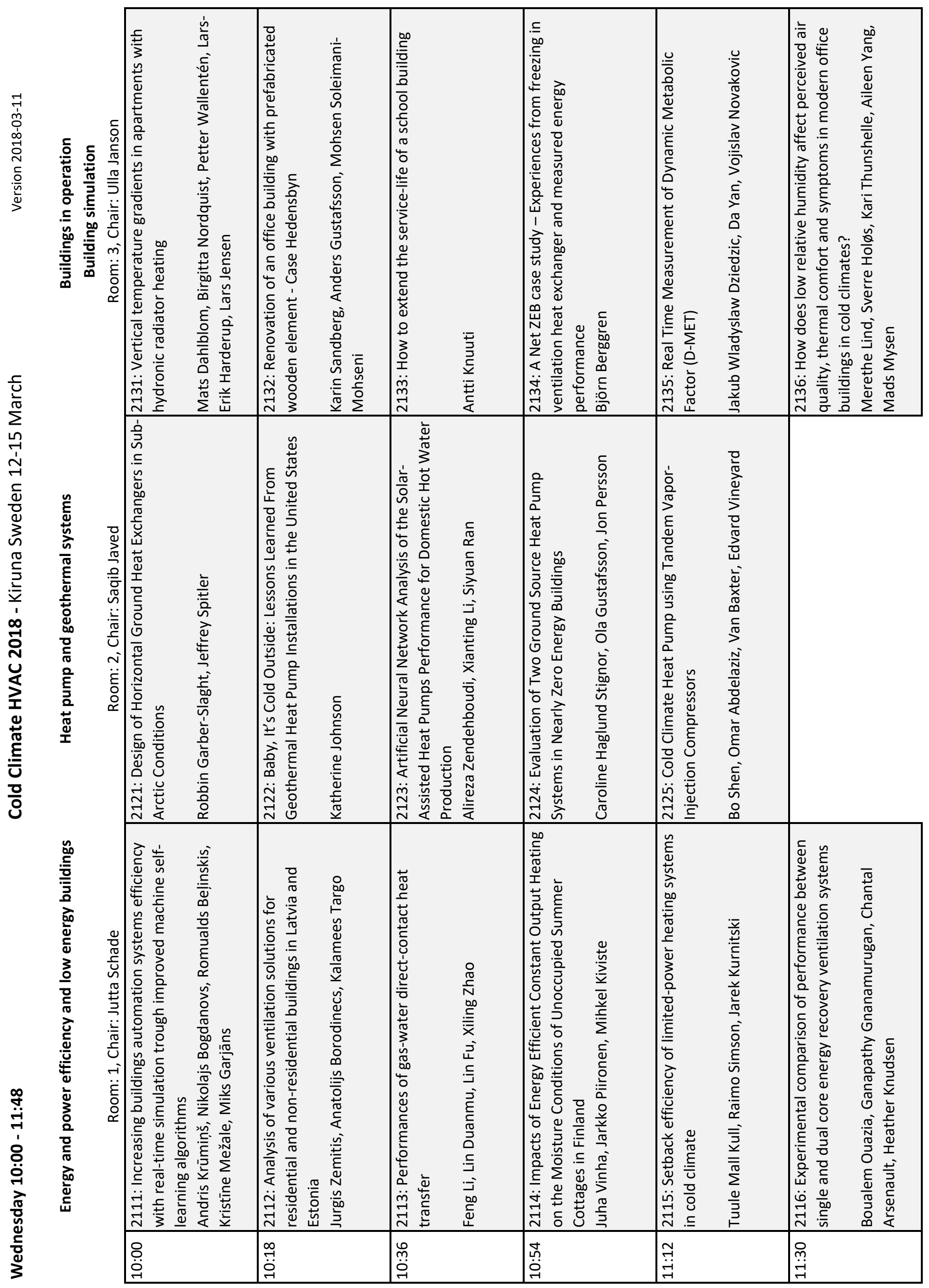




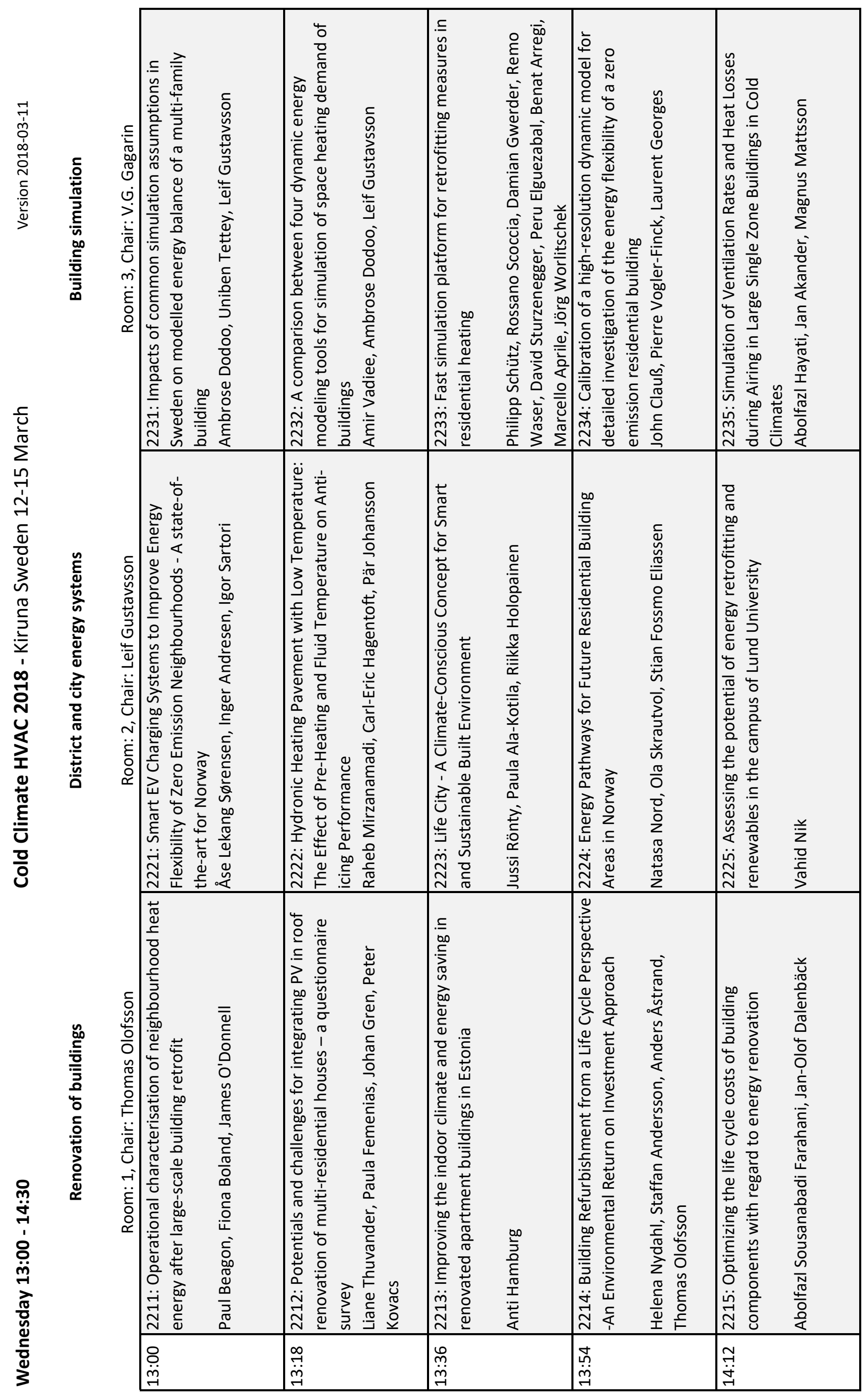





\section{Thursday}

8:00 - 9:30 Parallel Fieldtrips

Study visit to the mine ventilation system

Study visit to the new city hall

Architectural tour

9:30 - 10:00 Morning coffee, exhibition

10:00 - 11:30 Parallel paper sessions

Renovation of buildings

Other aspects of buildings in cold climates

Codes, regulations, standards and policies

11:30 Lunch at Scandic Ferrum

13:00 - 14:30 Parallel paper sessions

Energy and power efficiency and low energy buildings

Heat pump and geothermal systems, Construction management

14:30 - 15:00 Afternoon coffee, exhibition

15:00 -17:00 Keynote speaker: William Semple, Architect, University of Alberta, NORDEC Consulting and Design, Ottawa

William will talk about Environmental and Cultural Sustainability in the Canadian North: Engaging Indigenous Communities in the Design and Construction of Energy Efficient

Culturally Appropriate Northern Housing

Closing 


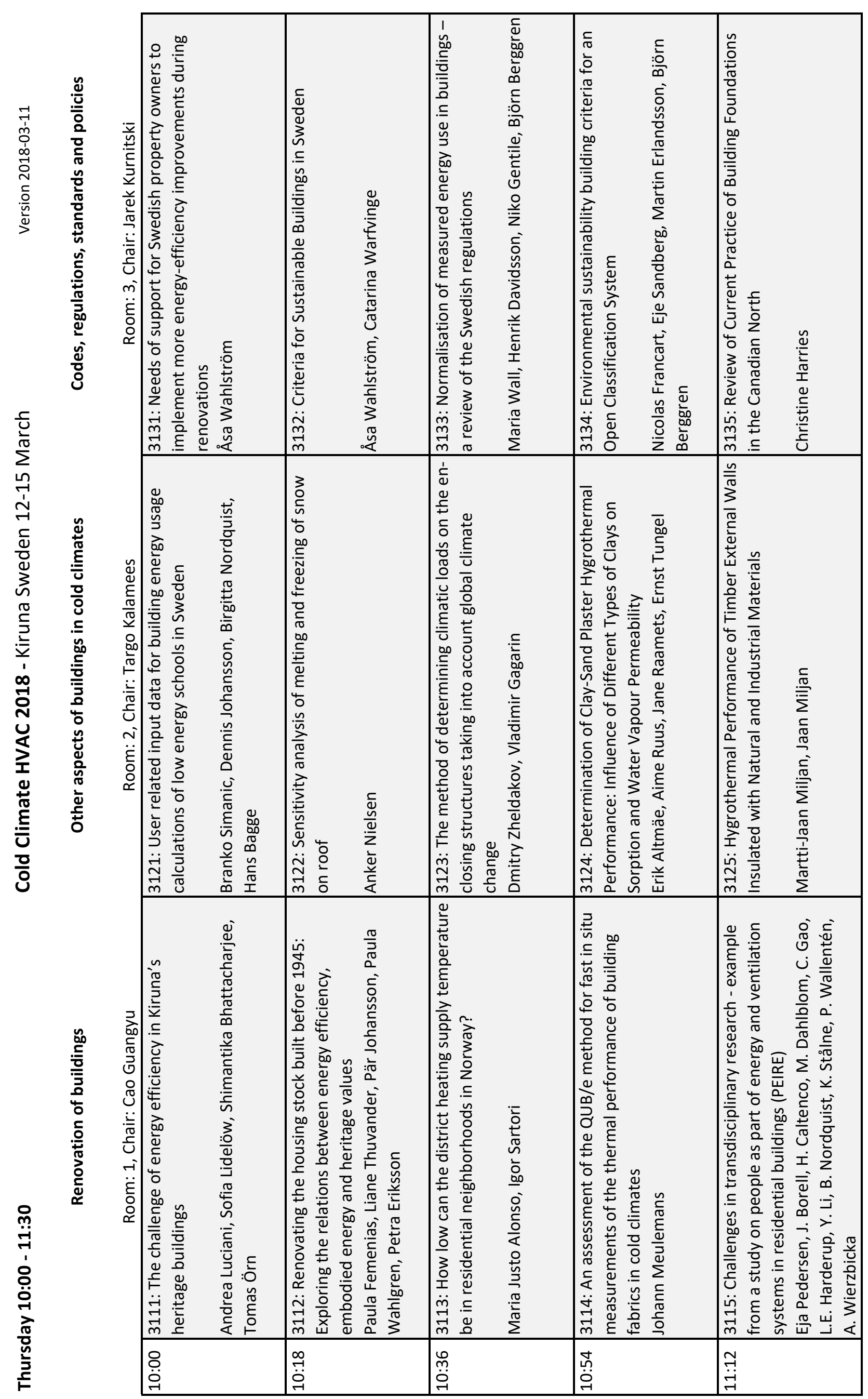




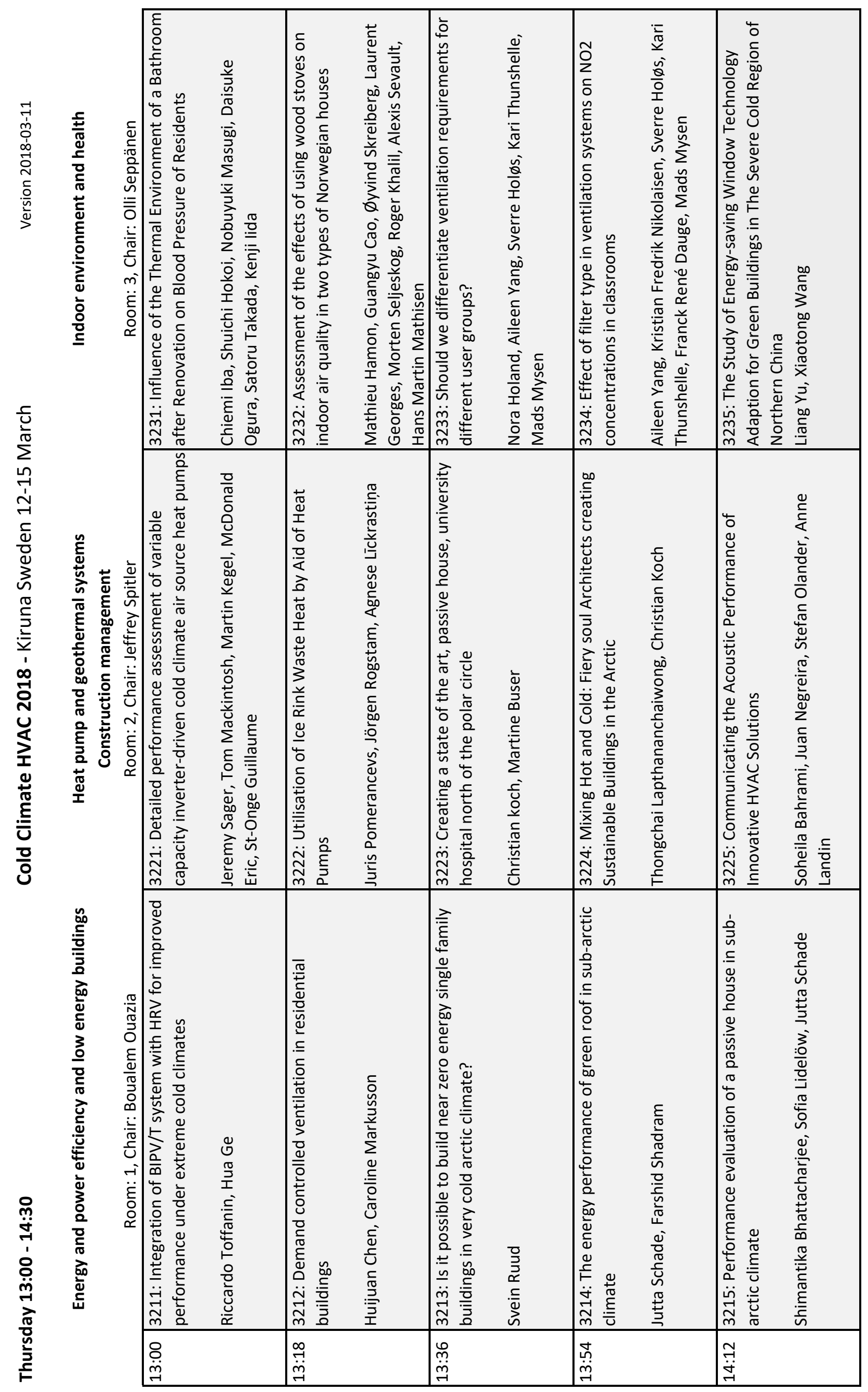





\section{Friday}

\section{Morning}

Parallel activities

Dog-sledding and lunch (Separate registration required)

Ice-fishing, short snowmobile ride and lunch (Separate registration required)

Snowmobile ride and lunch (Separate registration required)

\section{Afternoon}

Guided tour to Abisko (Separate registration required)

The bus leaves Kiruna at 14:00 and arrives in Abisko at 15:30. In Abisko there will be a guided walk along the canyon. Dinner in Abisko at 18:00. The bus leaves for Kiruna at 20:30 PM. During the drive back to Kiruna there will be stops to look for northern light "Aurora Hunting".

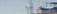




\section{Scientific committee}

Angela Sasic

Berit Time

Bert Phillips

Bill Semple

Björn Marteinsson

Boualem Ouazia

Carey Simonson

Carl-Erik Hagentoft

D.Y. Zheldakov

Eckhard Groll

Erich Binder

Guangyu Cao

Hans Martin Mathisen

Henrik Davidsson

Hiroshi Yoshino

Hua Ge

Ivo Martinac

Jan Sundell

Jan-Olof Dalenbäck

Jarek Kurnitski

Jeff Spitler

Jesper Arfvidsson

Juha Vinha

Jutta Schade

Karel Kabele

Kristina Mjörnell

Kwang Woo Kim

Lars-Erik Harderup
Chalmers University of Technology

SINTEF

UNIES Ltd.

University of Calgary

University of Iceland

National Research Council Canada

University of Saskatchewan

Chalmers University of Technology

Res. Inst. of building physics of RAACS, Moscow

Purdue University

WorleyParsons LTD

Norwegian University of Science and Technology

Norwegian University of Science and Technology

Lund University

Tohoku University

Concordia University

Royal Institute of Techonolgy, Stockholm

Tsinghua University

Chalmers University of Technology

Tallin University of Technology

Oklahoma State University

Lund University

Tampere University of Technology

Luleå Technical University

Czech Technical University in Prague

RISE

Seoul National University

Lund University 


\section{Scientific committee}

Leif Gustafsson

Lin Duanmu

Linda Hägerhed

Marianna Brodach

Martin Kotol

Mika Vuolle

Olli Seppanen

Paula Femenias

Pawel Wargocki

Petra Vladykova Bednarova

Robert Cerný

Saqib Javed

Shuichi Hokoi

Stefan Olander

Sven Werner

Svend Svendsen

Targo Kalames

Thomas Lützkendorf

Thomas Olofsson

Thoms Olofsson

Toke rammer Nielsen

Ulla Janson

V.G. Gagarin

Vojislav Novakovic

Xudong Yang

Åke Blomsterberg
Växjö Linnaeus University

Dalian University of Technology

University of Borås

Moscow Architectural Institute

Technical University of Denmark

EQUA

FINVAC

Chalmers University of Technology

Technical University of Denmark

Swegon

Czech Technical University in Prague

Lund University

Kyoto University

Lund University

Halmstad University

Technical University of Denmark

Tallinn University of Techonolgy

Karlsruhe Institute of Technology

Luleå Technical University

Umeå University

Technical University of Denmark

Skanska

Res. Inst. of building physics of RAACS, Moscow Norwegian University of Science and Technology Tsinghua University

Lund University 



\section{Conference organizing committee}

Dennis Johansson, Conference Chair

Lund University, Building Services

dennis.johansson@hvac.Ith.se

Hans Bagge, Conference Co-Chair

Lund University, Building Physics

hans.bagge@byggtek.Ith.se

Åsa Wahlström, Senior Advisor

Lund University, Building Services

asa.wahlstrom@hvac.Ith.se 
